\title{
Ordinary Transubstantiations: Gadamer's Notion of 'Speculative' and Material Logic of Hermeneutic Experience
}

\author{
ILYA INISHEV \\ School of Philosophy and Cultural Studies, National Research University Higher School of Economics, Myasnitskaya ul. 20, Moscow, \\ 101000, Russia \\ Email: inishev@hse.ru
}

\begin{abstract}
According to Gadamer, the main distinguishing feature of hermeneutic experience is its ontological dimension epitomized by complex and multilayered transformative processes expressed in such formulae as 'increasing in being,' 'transformation into the true' or 'total mediation'. This notion of ontological experience as a transformative event allows two readings. The weak reading of Gadamer's hermeneutic ontology (favoured by Gadamer himself as well as by all his interpreters and critics), laying the stress on interpreter's self-consciousness, contents itself with just 'subjective' side of transformative effects of hermeneutic experience. The strong treatment of transformative potential of hermeneutic experience, which corresponds better to the universality claim of philosophical hermeneutics, presupposes equally strong transformation affecting not only interpreter's self-consciousness but also her body as well as material environments of interpretive experience. We find the elements of such a 'strong' treatment of the transformative (i.e. ontological) potential of understanding in Gadamer's conception of the speculative, adumbrated in the concluding sections of his 'Truth and Method. Drawing on this conception, the paper proposes the notion of transubstantiation as a model for describing the bodily-material dimension of transformative processes making up the core element of hermeneutic ontology.
\end{abstract}

Keywords: hermeneutic experience, speculative medium, transubstantiation, materiality, perceptual faith

\section{INTRODUCTION}

Admittedly, almost all of Gadamer's philosophical queries revolve around the notion of hermeneutic experience understood as a kind of processual medium the distinguishing feature of which is its neutrality in regard to the difference between the agential and the spatial, which ultimately entails a radical creative disposition: an action being its own space. The action here is in a sense multidirectional, that is to say, it does not start in a detached sphere of thought and then, crossing the border of 'outer' space, moves within this space's always already established milieus and layers, but it rather emanates into a kind of common territory constituted by the hermeneutic encounter itself: a performative fusion of meaning and matter. 
Actually, this performative fusion is nothing less than the true core of Gadamer's project, especially if we take seriously his explicit ontological claims scattered across many pages of his 'Truth and Method'. To take them seriously - and this is my main thesis - means to interpret the notions of fusion and increase in being not just metaphorically but as literally as possible. And that is precisely what I am going to do.

I propose to treat the ontological aspect of Gadamer's project in terms of a 'real' transformative process. At the core of such a process and its 'reality' lies what I will refer to as 'transubstantiation' - the term of theological provenance by means of which I try to translate and at the same time radicalize Gadamer's notion of 'speculative' that I suppose comprises the very essence of hermeneutic ontology. While the notion of 'speculative' in Gadamer is modelled on the optical metaphor of performative interdependence of the mirroring (interpretation) and the mirrored (interpreted), 'transubstantiation' lays emphasis on circulation of matter within such a mirroring process.

On the one hand, this term and this thought goes quite beyond what Gadamer has ever said about the interpretation process. On the other hand, without taking into account the material dimension of hermeneutic experience, Gadamer's radical interpretive ontology will remain incomplete and even not fully understandable.

Although today there are many theoretical endeavours trying to overcome the conceptual and methodological constrains of Gadamer's initial project, none of them goes so far as to assert a unique potential of hermeneutic experience to bring about new material configurations and forms building up a sort of continuous livable space neutral to the categorical difference between mind and matter, thinking and acting, perceiving and imaging.

The article is divided into two sections. In the first one, I discuss the role and the sense of ontology as that which specifies Gadamer's hermeneutical project. As a main trait of this ontology I consider the notion of transformation which in Gadamer, I think, remains underarticulated. To give this notion its due weight, I unravel its implications, the main one of which is the idea of performatively transformable, i.e. speculative matter. In the second section, I put forward and defend the thesis that understanding, as it is conceived in philosophical hermeneutics, is a material process possessing its own logic and peculiar effects.

\section{HERMENEUTIC ONTOLOGY - AN UNACCOMPLISHED PROJECT}

We have been long accustomed to think of Gadamer's hermeneutical project in terms of ontology. Indeed, what makes the difference between traditional and philosophical hermeneutics is treating 'the hermeneutical as an ontological phenomenon' (Gadamer 2007: 56).

Nevertheless, despite the currency of the term, the ultimate sense of 'ontology' in philosophical hermeneutics remains underarticulated. The reason for it is the presence in Gadamer's work of at least two different, though interconnected, senses of 'ontology'. The first of them concerns 'ontology' as a set of questions addressing the proper being of a thing at issue. This proper being plays the role of the hidden ground of an experience and affects indirectly, if at all, explicit forms of knowledge and consciousness. The second sense refers not to presuppositions but to performance and effects of an experience: 'ontological' means here 'productive' which has to be understood in the most radical meaning: including, among other things, the reconfiguration of experiential reality 'into the true' (Gadamer 2013: 116). In 'Truth and Method', the distinction between these two senses of 'ontology' is manifested in the very structure of text: whereas the term 'ontology' appears periodically in the text of the first two parts of the book and even in the heading of the second section of the first part, 
the third, concluding part of the book pronounces expressly, and almost surprisingly, 'the ontological shift of hermeneutics', which sounds somewhat embarrassing because it feels like the ontological motif was twice introduced into hermeneutical discourse, and the second introduction has some priority over the first one.

In order to explain the interconnection as well as discordance between these two senses of ontology, I will start with a short discussion of what Gadamer refers to as hermeneutic experience. As will be clear shortly, the interrelation between two senses of ontology corresponds to the interrelation between spacial (or participative) and transformative (or creative) aspects of hermeneutic experience.

\section{Understanding as Transformative and Participatory Experience}

The main distinguishing feature of hermeneutic experience is the radical non-difference between experiential performance and its 'subject-matter'. This non-difference, along with other features such as ecstaticity (the mutual openness of all experiential elements), mediality (peculiar spatiality and temporality) and creativity (permanently transforming the perceptible into the meaningful), constitutes what Gadamer refers to as 'hermeneutic phenomenon' (Gadamer 2013: xxii).

Thus, unlike Husserl, Gadamer proposes the notion of non-intentional experience endowed with ontological priority over all other experiential forms. Whereas Husserl's intentionality, being the hidden activity embedded in each and every cognitive act, radically endorses the relational scheme of subjective transcendentalism, Gadamer's hermeneutic phenomenon is not so much an act as a constellation of multiple and heterogeneous elements, 'subjective' as well as 'objective' ones, fused into a vibrant, both meaningful and substantial, setting. Thus, hermeneutic experience is a peculiar process, or rather event, within which the particular and, at first glance, disparate elements such as acts, emotions, sounds, bodily movements, material surfaces and objects congeal into holistic, though structured, phenomenon which has no external borders. In this sense, we can speak here of a kind of agential, or performative spatiality.

But what exactly does the space look like where such a self-transcendence and mutual openness, or interpenetration of the understanding and the understood take place?

\section{The Medial: Underarticulated Topology}

In 'Truth and Method' Gadamer uses the noun 'medium' as well as the adjective 'medial' to designate the spatial specificity of hermeneutic experience. There are two aspects to it. The first is represented by 'medial' and consists in paying attention to 'substantial' character of play, its processual and structural autonomy in relation to which the consciousness of a player involved serves only an auxiliary function. The second aspect puts more emphasis on the transformative potential of the hermeneutic experiential space.

In the third, decisive, part of 'Truth and Method' Gadamer speaks of language-like medium (Sprachlichkeit) building up a sort of transformative space common to all, human as well as non-human, elements of hermeneutic phenomenon. Transformative potential consists here in the peculiar melting and concurrent fusion of material substrate und human's interpretive performance into a new and unique presence which Gadamer refers to as 'a speculative unity': in hermeneutic experience, that which is to be understood - and sometimes that means just to be perceived as a part of a 'meaningful', that is, livable world - 'comes into 
language'. Coming into language (Zur-Sprache-kommen), as Gadamer puts it, 'does not mean that a second being is acquired. Rather, what something presents itself as belongs to its own being' (Gadamer 2013: 491). This 'speculative movement' between the modes of self-presentation and the ones of being unfolds as the 'language' which in this case (such is my thesis) is neither a means of symbolic expression of 'outer' reality nor a specific activity of human being but rather an aggregate state of experiential environment. How should we conceive of this aggregate state? How precisely do material settings become language, and language the space for appearance of perceptible world?

To answer these questions, we have to move beyond topological explanations (the medial as space of connection) towards considering the material dynamics of hermeneutic experience (the medial as space of production).

\section{The Missing Consideration of Matter}

To begin with, I would like to point out some inconsistency in Gadamer's philosophical project, which considerably undercuts its ontological universality claimed by the author in the final section of his opus magnum. The inconsistency I am talking about concerns the discrepancy between the universal scope of hermeneutic phenomenon and the basic examples by which this universality is exposed and explained: engaged experiences of art; pre-theoretical ways of perceiving the historical tradition; rare and very demanding forms of verbal communication.

All these realms deal either with immaterial or with technologically as well as practically malleable objects and settings capable of smoothly embedding into all kinds of human activities, e.g. concepts, texts and artifacts. The overall focus on things of this kind cannot but entail a neglect of specific material conditions (and respective logic) of hermeneutic experience, without which Gadamer's universality claim remains half-hearted, i.e. vulnerable to subjectivist interpretations.

\section{THE MATERIAL LOGIC OF HERMENEUTIC EXPERIENCE}

\section{Understanding as Mattering}

Understanding, as Gadamer treats it, is a kind of creative process - a kind of conditioning the material elements, perceptual settings and bodily feelings, aimed at creating the primary space in which all possible thoughts, imaginary objects and purposive acts can only be produced. How is a conditioning of this sort possible? How does matter undergo all the transformations that are necessary for the aforementioned conditioning, and that go far beyond the scope of tensility naturally pertinent to physical objects?

To answer these questions, I will draw on Gadamer's notion of 'speculative' as well as on numerous clues scattered across his later works.

In his short essay 'About Reading of Buildings and Images' (Gadamer 1993: 331-338), Gadamer tries to extend his 'logic of question and answer', mostly elaborated in the context of understanding of a written tradition, to material artefacts and structures, namely buildings and images. As compared to the 'Truth and Method', where image and architecture also play a crucial role, supporting the general thesis on the 'total' character of mediation between the represented content and its interpretation, this essay puts more emphasis on the material and sensual side of the question. The model for such kinds of experience is the reading process - 'All of our experience is a reading' (Gadamer 1990: 92). 
The reading, as Gadamer understands it in his later writings, is not a mental process of deciphering a pre-given meaning but, on the contrary, a process of gradually and painstakingly articulating the 'outer' material world and the 'feeling' body into inhabitable and vibrant whole which Gadamer calls 'das Gebilde' awkwardly translated into English as 'structure' (Gadamer 1993: 337). In other words, the main and only goal of such a reading is 'to let something speak again' (Gadamer 1993: 333), to 'bring it into language' (Gadamer 2013: 504). The 'language' and the 'speaking' mean here the 'speculative event', or 'speculative medium' (Ibid.) - a performative concretion of understanding and mattering.

\section{The Speculative and the Notion of Transubstantiation: An Attempt at Translation}

Gadamer first introduced his notion of the speculative as an ontological model of hermeneutic phenomenon in the two final sections of the third part of 'Truth and Method', which remain the only place where he discusses this concept more or less systematically. Gadamer treats 'speculation' in the simple and at the same time unusual manner. On the one hand, 'the word "speculative" here refers to the mirror relation' (Gadamer 2013: 481). On the other hand, there is something very peculiar about that mirroring. It works as a mutual reflection of the perceiving (interpreting) mind and interpreted 'thing' in each other. This reciprocal mirroring, or 'speculative movement' forms a 'speculative unity' that is 'a distinction, that between its [interpreted thing's] being and its presentations of itself, but this is a distinction that is really not a distinction at all' (Gadamer 2013: 491). This seemingly contradictory statement means that the both elements of speculative event, or movement - interpretation and interpreted - incessantly exchange matter with each other. What comes into language, which means what becomes a language, does it through the medium, or event of interpretation, including its various material sources such as sounds, imagination, scripts, sensorimotor reactions, affects, etc. that in turn acquire their full articulation only through getting involved in the 'speculative event' (Gadamer 2013: 504). Such getting involved presupposes a kind of borrowing someone's or something's material substrate in order to make possible an appearance of another person or thing. This borrowing in turn is always accompanied by another two steps on the path towards the aforementioned speculative unity, or - what is the same thing - language, namely transubstantiation and mediation. While the first term means that material substrate changes its 'owner' and therefore both its textural and structural qualities, the second one highlights the correlative shift in its 'ontological' position - a move from the initial position of 'property' to that of a 'medium'. All together, these steps entail the overall perceptual modification of matter that could be referred to as 'intensification': matter is no longer just present (extensive) but generative, productive, implosive (intensive).

Now I am going to explain Gadamer's notion of speculative medium by two examples: (1) the 'eminent' forms of verbal language and (2) 'strong' visual images - both are Gadamer's favourite research objects in his later period.

(1) According to Gadamer, only few types of verbal communicative experience can be subsumed under the category of hermeneutic experience. Among them there are engaged and open-ended discussion of some significant question (hermeneutic dialogue); a highly motivated reading of philosophical, fictional and historical texts; the Christian sermon; but first and foremost, lyric poetry ('eminent text'). The common distinguishing feature of these varieties of verbal experience is inseparability of 'utterance's' content and medium. The content here cannot be distilled from the whole 'speech act' as its immaterial core or information comprised in it. 
Key moment here is the mutual mirroring of world and language. In 'hermeneutic dialogue, for example, we deal thematically with a world that shows up at that moment only in the sound of communicative speech which in turn is manifest only in this act and, more importantly, as this act of (self-)revealing of the world in the visual-audial communicative milieu. Event of the world and event of the language coincide, fusing their substrates into a 'speculative unity'. In these cases, matter of sound changes its 'owner' (transubstantiation), being transferred from a speech to an object in question, or from hearing to seeing, and in this transferring, it does not remain an object's 'property' but becomes an environment for object's (self-)revealing (mediation).

(2) While verbal language phenomena are indispensable as a universal model for explication of the key features of speculative medium per se, the model of visual image is highly helpful for demonstrating how these features 'work' beyond the scope of verbal forms of hermeneutic phenomenon.

Here, as with the verbal embodiment of hermeneutic phenomenon, only few types of 'visual representation' come into question - namely that which fall under the category of the Image (das Bild), or 'strong' image (starkes Bild), as Gottfried Boehm puts it (Boehm 2007: 252). According to Gadamer, the Image is first and foremost not an object endowed with cultural value but an event, or process producing effects of a special kind: 'an increase in being' (Gadamer 2013: 141). The gap between these two poles - event and object - is filled in by a material-perceptual process that I refer to as transubstantiation.

A perception of two-dimensional picture, whether painted or photographic, can serve as an example of such a process. Specificity of pictures of such a kind - regardless of differences in styles and genres - consists in a particular arrangement and, respectively, a particular 'ontological' status of their material pictorial surface. Visible properties of this surface have a double attribution: they can be attributed either to the material vehicle of a picture (1) or a to depicted scene (2).

In both cases, we deal with the same object but with different 'aggregate states' of its material substrate: looking at the same 'object' (pictorial surface), we nevertheless perceive either measurable properties (size, outline, hue) of a physical object (a picture) or experiential and virtual (generative) milieu through which, or, rather, with which scenes, things, and their configurations become visually present (Image). In the latter case, the material substrate is completely absorbed by the depicted scene which in its turn cannot be visually (let alone physically) separated from the material substrate of pictorial surface it articulates by performatively integrating in it the bodily, emotional and cognitive resources provided by interpreter. In other words, what actually occurs in this perceptual process is the interchange of matter between its elements, which entails the inseparability of the material and intellectual aspects of hermeneutic experience.

In the next subsection, I will discuss this interchange as part of the 'material logic' pertinent to hermeneutic experience.

\section{Transubstantiation and the Material Logic of Hermeneutic Experience}

I take as an example the scenario of conversation developing along the line from small, highly ritualized talk to what Gadamer calls proper, or hermeneutical dialogue.

When we enter into communicative exchange with each other or perform visual perception of culturalized material environments such as a pictorial surface, architectural space or landscape, we go through several stages of the process of conditioning the related material 
forms. For example, when we talk to someone in everyday context of ordinary and highly patterned forms of communication such as the check-in process at a hotel, we are only interested in successful accomplishment of a standard task. The words we utter on such an occasion function as an integral part of a long-established social ritual, being almost completely absorbed by it. The material components, both of environment and of communication itself, hardly play any substantial role in such an event that, actually, is neither communicative nor interpretive in the proper sense.

But as a matter of fact, many communicative events that are not restricted to the situation mentioned above, proceed, as a rule, to the next two stages. First of them is the so-called 'exchange of views': the process of transferring the linguistically articulated 'contents' from one 'consciousness' to another, filtered through a subject's interpretive and critical engagement.

In this case, matter works just as support, or vehicle for immaterial meanings. Actually, it is precisely that configuration which Habermas' communicative rationality is modelled on (Habermas 2018: 88-94).

In some instances, a communication process may develop into what Gadamer calls 'hermeneutic dialogue' (Gadamer 2013: 387, 582). The moral and social aspect of this kind of conversation consists in transforming its participants into 'a communion in which we do not remain what we were' (Gadamer 2013: 387). But this type of transformation is necessarily accompanied by another one: language and world merge into the same experiential medium within which they exchange matter with each other, producing the material configurations that have not existed before.

Matter here is not a passive and just facultative vehicle for immaterial meaning; it is not just 'given', or extensive but becomes a kind of evocative, or generative and in this sense intensive medium functioning as a radically free space, or a zero point (the point of departure) of all possible experiential configurations - the pure potentiality that exceeds any actual presence.

Thus, none of just sketched phases of development of hermeneutic experience is able to occur without the correlative aggregate state of its material environment. The final and highest phase of this development - the full-fledged, that is hermeneutical understanding - ends up as creative material praxis turning matter into the speculative medium, which I reinterpret as transubstantiation - an event the subjective reflex of which is not a religious but rather perceptual faith. This is precisely what I refer to as the material logic of hermeneutic experience.

\section{CONCLUSIONS}

In this article, I have proposed an interpretation of (ontological) hermeneutic experience as a transformative perceptual-material event affecting both the bodily conditions and material environment of 'understanding. In other words, hermeneutic experience implies a peculiar productivity - the occasional creation of the unique bodily-material milieu (a kind of a 'zero space') the normative horizon of which is set by the two interrelated processes: intensification of the material (the shift from physical matter to generative one) and maximization of the bodily self-presence. These two processes intersect at, and are based on, what I refer to as 'transubstantiation' - an exchange of performative matter within ordinary acts of perceptual faith: 'In understanding we are drawn into an event of truth and arrive, as it were, too late, if we want to know what we are supposed to believe' (Gadamer 2013: 506).

Received 24 March 2020 Accepted 25 October 2020 


\section{References}

1. Barad, K. 2007. Meeting the Universe Halfway. Quantum Physics and the Entanglement of Matter and Meaning. Durham, London: Duke University Press.

2. Bennett, J. 2010. Vibrant Matter. A Political Ecology of Things. Durham, London: Duke University Press.

3. Boehm, G. 2007. Wie Bilder Sinn erzeugen. Berlin: Berlin University Press.

4. Davey, N. 2017. 'The (impossible) Future of Hermeneutics', Journal of the British Society for Phenomenology 48(3): 209-221.

5. DeNora, T. 2014. Making Sense of Reality: Culture and Perception in Everyday Life. London: Sage Publications.

6. Gadamer, H.-G. 1990. 'Hearing-Seeing-Reading', Language \& Communication 10(1): 87-91.

7. Gadamer, H.-G. 1993. Ästhetik und Poetik I. Kunst als Aussage (Gesammelte Werke, Bd. 8). Tübingen: Mohr Siebeck.

8. Gadamer, H.-G. 2013. Truth and Method. New York, London: Bloomsbury.

9. Gadamer, H. G. 2007. 'Classical and Philosophical Hermeneutics', in The Gadamer Reader: A Bouquet of the Later Writings, ed. R. Palmer. Evanston: Northwestern University Press, 41-71.

10. Gallagher, S.; Martínez, S. F.; Gastelum, M. 2017. 'Action-Space and Time: Towards an Enactive Hermeneutics', in Place, Space and Hermeneutics, ed. B. Janz. Springer, 83-96.

11. Gamble, Ch.; Hanan, J.; Nail, Th. 2019. 'What is New Materialism?', Angelaki. Journal of the Theoretical Humanities 24(6): 111-133.

12. Habermas, J. 2018. Philosophical Introductions. Five Approaches to Communicative Reason. Cambridge: Polity Press.

13. Hayles, K. 2014. 'Cognition Everywhere: The Rise of the Cognitive Nonconscious and the Costs of Consciousness', New Literary History 45(2): 199-220.

14. Hodder, I. 2012. Entangled: An Archaeology of the Relationships between Humans and Things. Oxford: WileyBlackwell.

15. Ihde, D. 1999. Expanding Hermeneutics. Visualism in Science. Evanston: Northwestern University Press.

16. Ingold, T. 2000. The Perception of the Environment. Essays on Livelihood, Dwelling and Skill. London, New York: Routledge.

17. Ingold, T. 2010. 'Ways of Mind-walking: Reading, Writing, Painting', Visual Studies 25(1): 15-23.

18. Kearney, R.; Treanor, B. (ed.). 2015. Carnal Hermeneutics. New York: Fordham University Press.

19. Malafouris, L. 2013. How Things Shape the Mind: A Theory of Material Engagement. Cambridge: Massachusetts Institute of Technology.

20. Meillassoux, Q. 2008. After Finitude. An Essay on the Necessity of Contingency. New York: Continuum.

21. Merleau-Ponty, M. 2007. 'Eye and Mind', in The Merleau-Ponty Reader, eds. T. Toadvine and L. Lawlor. Evanston: Northwestern University Press, 351-378.

22. Mersch, D. 2010. Posthermeneutik. Berlin: Akademie Verlag.

23. Nancy, J.-L. 2016. 'The Image: Mimesis and Methexis', in Nancy and Visual Culture, eds. C. Giunta and A. Janus. Edinburgh: Edinburgh University Press, 73-92.

24. Romano, C. 2009. Event and World. New York: Fordham University Press. 
ILYA INISHEV

\title{
Paprastos transsubstanciacijos: H.-G. Gadamerio „spekuliatyvumo“ samprata ir materiali hermeneutinès patirties logika
}

\begin{abstract}
Santrauka
H.-G. Gadamerio teigimu, pagrindinis skiriamasis hermeneutinės patirties bruožas yra jos ontologinè dimensija, kondensuota sudètingais daugiasluoksniais transformatyviais procesais, išreikštais tokiomis formuluotemis kaip „būties pagausèjimas“, „transformacija ị tikra" ar "totalinè medijacija“. Šią ontologinès patirties kaip transformatyvaus ìvykio sampratą galima traktuoti dvejopai. Silpnoji H.-G. Gadamerio hermeneutinès ontologijos traktuotè (jai pirmenybę teikè pats Gadameris, taip pat visi jo interpretatoriai ir kritikai), akcentuodama interpretatores savimonę, apsiriboja tik „subjektyvia“ transformatyvių hermeneutinès patirties efektų puse. Stiprioji transformatyvaus hermeneutinès patirties potencialo traktuotè, kuri geriau dera su filosofinès hermeneutikos universalumo siekiu, numato ne mažiau stiprią transformaciją, paveikiančią ne tik interpretatores savimonę, bet ir jos kūną bei materialią interpretatyvios patirties aplinką. Tokios „stipriosios“ transformatyvaus (t. y. ontologinio) supratimo potencialo traktuotès elementų aptinkame H.-G. Gadamerio spekuliatyvumo koncepcijoje, gvildenamoje baigiamuosiuose Tiesos ir metodo skyriuose. Remiantis šia koncepcija, straipsnyje siūlomas modelis - transsubstancijacijos samprata - hermeneutinès ontologijos pagrindui priklausančiai kūniškai-materialiai transfomatyvių procesų dimensijai aprašyti.
\end{abstract}

Raktažodžiai: hermeneutine patirtis, spekuliatyvi medija, transsubstancijacija, materialumas, perceptinis tikejjimas 